\title{
Comprehensive analysis of the renal transcriptional response to acute uranyl nitrate exposure Magali Taulan ${ }^{1,2}$, Francois Paquet ${ }^{1}$, Angel Argiles ${ }^{3}$, Jacques Demaille ${ }^{\dagger 2}$ and Marie-Catherine Romey*†
}

Address: 'Laboratoire de radiotoxicologie expérimentale, Institut de Radioprotection et de Sûreté Nucléaire, Site du Tricastin, BP 16626702 Pierrelatte Cedex, France, ${ }^{2}$ Laboratoire de Génétique Moléculaire, UPR 1142, Institut de Génétique Humaine, 141 Route de la Cardonille, 34396 Montpellier Cedex 05, France and ${ }^{3}$ Laboratoire de Génomique Fonctionnelle, UPR 2580, Institut de Génétique Humaine, 141 rue de la Cardonille, 34396 Montpellier Cedex 5, France

Email: Magali Taulan - magali.taulan@igh.cnrs.fr; Francois Paquet - françois.paquet@irsn.fr; Angel Argiles - angel.argiles@igh.cnrs.fr; Jacques Demaille - jacques.demaille@igh.cnrs.fr; Marie-Catherine Romey* - Marie-Catherine.Romey@igh.cnrs.fr

* Corresponding author †Equal contributors

Published: II January 2006

BMC Genomics 2006, 7:2 doi:10.1/86/147/-2164-7-2
Received: 16 September 2005

Accepted: II January 2006

This article is available from: http://www.biomedcentral.com/I47I-2/64/7/2

(c) 2006 Taulan et al; licensee BioMed Central Ltd.

This is an Open Access article distributed under the terms of the Creative Commons Attribution License (http://creativecommons.org/licenses/by/2.0), which permits unrestricted use, distribution, and reproduction in any medium, provided the original work is properly cited.

\begin{abstract}
Background: Chemical and radiological toxicities related to uranium acute exposure have been widely studied in nuclear fuel workers and military personnel. It is well known that uranyl nitrate induces acute renal failure (ARF). However, the mechanisms of this metal-induced injury are not well defined at the molecular level.

Results: Renal function and histology were assessed in mice receiving uranyl nitrate $(\mathrm{UN}(+))$ and controls $(U N(-))$. To identify the genomic response to uranium exposure, serial analysis gene expression (SAGE) of the kidney was performed in both groups. Over 43,000 mRNA SAGE tags were sequenced. A selection of the differentially expressed transcripts was confirmed by real-time quantitative PCR and Western blotting. $\mathrm{UN}(+)$ animals developed renal failure and displayed the characteristic histological lesions of UN nephropathy. Of the $>14,500$ unique tags identified in both libraries, 224 had a modified expression level; they are known to participate in inflammation, ion transport, signal transduction, oxidative stress, apoptosis, metabolism, and catabolism. Several genes that were identified had not previously been evaluated within the context of toxic ARF such as translationally controlled tumor protein, insulin like growth factor binding protein 7 and ribosomal protein $\mathrm{S29}$, all apoptosis related genes.

Conclusion: We report a comprehensive description of the UN induced modifications in gene expression levels, including the identification of genes previously unrelated to ARF. The study of these genes and the metabolisms they control should improve our understanding of toxic ARF and enlighten on the molecular targets for potential therapeutic interventions.
\end{abstract}

\section{Background}

Uranium (U) is a heavy metal, which has a wide range of uses that invariably carry an exposure risk for industrial workers as well as for the general population. After an accidental absorption of $U$ compounds, the soluble form of $U$ is carried in the blood, filtered by the glomerulus and partly excreted in the urine. Uranyl nitrate (UN)-induced nephropathy has been extensively studied in animal mod- 
Table I: List of global analysis studies on the kidney

\begin{tabular}{llll}
\hline Study & Methods & $\begin{array}{l}\text { Conditions } \\
\text { Injury or physiologic }\end{array}$ & Species and tissue \\
\hline $\begin{array}{l}\text { A. Global analysis studies in ARF } \\
\text { Basile et al. (2005) }\end{array}$ & microarray & ischemia-reperfusion & Rat kidney \\
Kieran et al. (2003) & microarray & ischemia-reperfusion & Mouse kidney \\
Mishra et al (2003) & microarray & ischemia-reperfusion & Rat kidney \\
& microarray & cisplatin & Mouse kidney \\
Supavekin et al. (2003) & microarray & ischemia-reperfusion & Mouse kidney \\
Yoshida et al. (2002) & microarray & ischemia-reperfusion & Mouse kidney \\
Yoshida et al. (2002) & microarray & ischemia-reperfusion & Rat kidney \\
Huang et al. (200I) & microarray & cisplatin & Rat kidney \\
B. Global analysis providing control & positive data to validate our SAGE libraries & Human kidney \\
Chabardés-Garonne et al. (2003) & SAGE & normal & Mouse kidney \\
Cheval et al. (2002) & SADE* & normal & Mouse kidney \\
Elalouf et al (2002) & SADE* & normal & Mouse Kidney \\
Schelling et al. (2002) & SAGE & normal & Human kidney \\
Yano et al. (2002) & microarray & normal & Mouse kidney \\
El-Meanawy et al. (2000) & SAGE & normal/ & glomerulosclerosis-prone \\
Virlon et al. (1999) & SADE* & normal & Mouse kidney \\
\hline
\end{tabular}

*SAGE Adaptation for Downsized Extracts

els. [1-3] It mainly involves the S3 segment of the proximal tubule [2].

Many studies on toxicant or ischemia-induced acute renal failure (ARF) have provided data demonstrating the participation of a wide range of compounds that are known to modulate several processes such as nephrogenesis, regenerative response and inflammation [4-11]. However, the bulk of knowledge on ARF at the molecular level, has been achieved with work that focused on a single molecule or pathway characterization $[6,11]$.

The tremendous progress recently accomplished in biotechnology has made possible to analyze thousands of transcripts in a single experiment, thereby offering a powerful strategy in the study of transcriptome. Some studies have been already performed to analyze the genomic responses in various types of ARF (table 1) [12-17]. However, many aspects remain to be unraveled in ARF. Here, we described for the first time the renal toxicogenomics effects of UN-induced ARF via SAGE (Serial Analysis of Gene Expression) technology. The potential of this approach for the discovery of novel toxicant-induced gene expression alterations has been already highlight following UN-long term exposure [18]. In addition, the choice of SAGE versus microarray hybridization technique depends on several factors, such as the scope of the genetic screen, the number of samples, the amount of starting material and the availability of resources such as an auto- mated DNA sequencer. Unlike microarray approaches, SAGE is an unbiased method in that it does not require a priori knowledge of genes of interest and is therefore not constrained by sequences on a chip. Furthermore, SAGE data contains expression information for every tag (gene) relative to every other tag in a given library and so requires minimal normalization and, since it generates immortal data, can be readily shared between laboratories. In addition, although both functional and histologic damages resulting from uranium exposure have been well established, little is known about molecular effects of UN contamination. Therefore, we chose SAGE approach to provide a comprehensive view of the molecular events involved in the early phase of UN-induced ARF. Our results demonstrate a variation in the expression rate of $\mathrm{i}$ ) genes previously related to both, ischemic and toxic ARF (including UN-induced ARF), ii) genes that were known to be related to the various types of ARF, but not to participate in UN-induced ARF and iii) genes that were not known to participate in either type of ARF such as translationally controlled tumor protein (TCTP), insulin like growth factor binding protein 7 (IGFBP7) and ribosomal protein S29 (Rps29).

\section{Results \\ Characterization of UN-induced ARF}

All the animals included in the study survived at either UN or vehicle injections. As expected, only the animals receiving UN injections developed ARF. Tissue levels of 
Table 2: SYBR Green (a) and Taq Man primers (b) sequences used for RT PCR reactions.

\begin{tabular}{|c|c|c|c|}
\hline GeneSymbol & Accession No. & Primer 5' -> 3' sequence & Amplicon size (bp) \\
\hline \multicolumn{4}{|c|}{ a. Primers using SYBR Green detection } \\
\hline \multirow[t]{2}{*}{ Hprt } & NM 013556 & Forward 5'-TTGCTGACCTGCTGGATTAC-3' & 112 \\
\hline & & Reverse 5'-CCCGTTGACTGATCATTACA-3' & \\
\hline \multirow[t]{2}{*}{ Sodl } & $\underline{X M \quad 128337}$ & Forward 5'-TGGTGGTCCATGAGAAACAA-3' & 75 \\
\hline & & Reverse 5'-TCCCAGCATTTCCAGTCTTT-3' & \\
\hline \multirow[t]{2}{*}{ Ftll } & NM 010240 & Forward 5'-TGTGCAGAAGCCATCTCAAG-3' & 99 \\
\hline & & Reverse 5'-AGATCCAAGAGGGCCTGATT-3' & \\
\hline \multirow[t]{2}{*}{ Opn } & NM 009263 & Forward 5'-GACCATGAGATTGGCAGTGA-3' & 110 \\
\hline & & Reverse 5'-GGTGCAGGCTGTAAAGCTTC-3' & \\
\hline \multirow[t]{2}{*}{ Odc } & NM 013614 & Forward 5'-TTGCCACTGATGATTCCAAA-3' & 129 \\
\hline & & Reverse 5'-CATGGAAGCTCACACCAATG-3' & \\
\hline \multirow[t]{2}{*}{ Calm2 } & NM 007589 & Forward 5'-CATGGCTGACCAACTGACTG-3' & 103 \\
\hline & & Reverse 5'-CCCCAGCTCСTTTGTTGTTA-3' & \\
\hline \multirow[t]{2}{*}{$\operatorname{lgfbp} 7$} & NM 008048 & Forward 5'-GCATCCAGCCACCTTATGAT-3' & 105 \\
\hline & & Reverse 5'-ATCCGAAGAGGAGGAAGAGG-3' & \\
\hline \multirow[t]{2}{*}{ Rps29 } & NM 009093 & Forward 5'-ACGGTCTGATCCGCAAATAC-3' & 138 \\
\hline & & Reverse 5'-CATGATCGGTTCCACTTGGT-3' & \\
\hline \multirow[t]{2}{*}{ Tctp } & NM 009429 & Forward 5'-CCGGGAGATCGCGGAC-3' & 92 \\
\hline & & Reverse 5'-TTCCACCGATGAGCGAGTC-3' & \\
\hline \multicolumn{4}{|c|}{ b. Primers using Taq Man technology Assay ID (Assay On Demand, Applied Biosystems) } \\
\hline Hprt & NM 013556 & Mm00446968m I & \\
\hline Kap & NM 010594 & $\mathrm{Mm00495104m \textrm {l }}$ & \\
\hline Umod & NM 009470 & Mm00447649ml & \\
\hline NaPi-II & NM 011392 & Mm0044I450ml & \\
\hline
\end{tabular}

uranium were significantly increased in $\mathrm{UN}(+)$ group compared to UN(-) group $(15.8 \pm 5.6 \mu \mathrm{g} / \mathrm{g}$ vs. $0.3 \pm 0.9$ $\mu \mathrm{g} / \mathrm{g}, \mathrm{p}<0.001)$.

\section{Renal function}

Urea and creatinine serum levels significantly increased in $\mathrm{UN}(+)$ group as early as day 2 (figure $1 \mathrm{~A}$ ). Urinary $\gamma \mathrm{GT}$ also significantly increased and glucose was detected in $\mathrm{UN}(+)$ group (figure 1A).

\section{Morphological changes}

UN injected animals displayed an important tubular vacuolization and a focal loss of brush border in proximal tubular cells (figure 1B). The score of proximal tubules (PT) damage in outer stripe of outer medulla (S3 segments) compared to UN(-) tissue was increased as early as day 2 (between 25 and 50\% of PT damaged). The overall structure of the kidney was preserved and glomerulae were intact in appearance. These findings are well in keeping with previous reports [19]. Because it is well known that changes in gene expression occur soon after a renal insult, we decided to examine the early response of an UN contamination. Although, the histological observations are not very convincing, we chose genome-wide geneexpression approach because it allows more sensitive end points to evaluate renal impact of UN treatment.

\section{Global gene expression in UN-induced ARF}

The sequence analysis of $\approx 43,000$ transcripts from the kidneys of $U N(-)$ and $U N(+)$ tags was performed. The vast majority of these tags represent distinct transcripts. However, some tags, especially those detected only once, may result from PCR or sequencing errors [20]. More than 7,900 and 6,800 distinct tags were obtained in UN(-) and $\mathrm{UN}(+)$ animals, respectively.

The good quality of the obtained libraries could be confirmed based on the previously reported renal transcriptomes (table 1) [21-27]. As expected, we predominantly found, tags specific for proximal tubule, as it represents the bulk of kidney's weight. Further, a large fraction of the most abundant tags matches with widely expressed mitochondrial genes or ribosomal proteins. The high levels of mitochondrial DNA-encoded transcripts are consistent with the high-energy demand of the kidney and have been previously noted in kidney SAGE libraries by other investigators $[26,27]$. In addition, in agreement with previous data, the most frequently observed tags corresponded to glutathione peroxidase 3 (GPx3) $(2.1 \%)$ and KAP $(1.4 \%)$ genes [26].

Data analyses showed that 2,518 tags (61.4\%) match with known genes, 223 retained tags (5.4\%) do not match with characterized mouse genes or cDNAs. When considering EST databases, 347 tags (8.5\%) match with anonymous sequences. One thousand and sixteen tags $(24.7 \%)$ are 
A
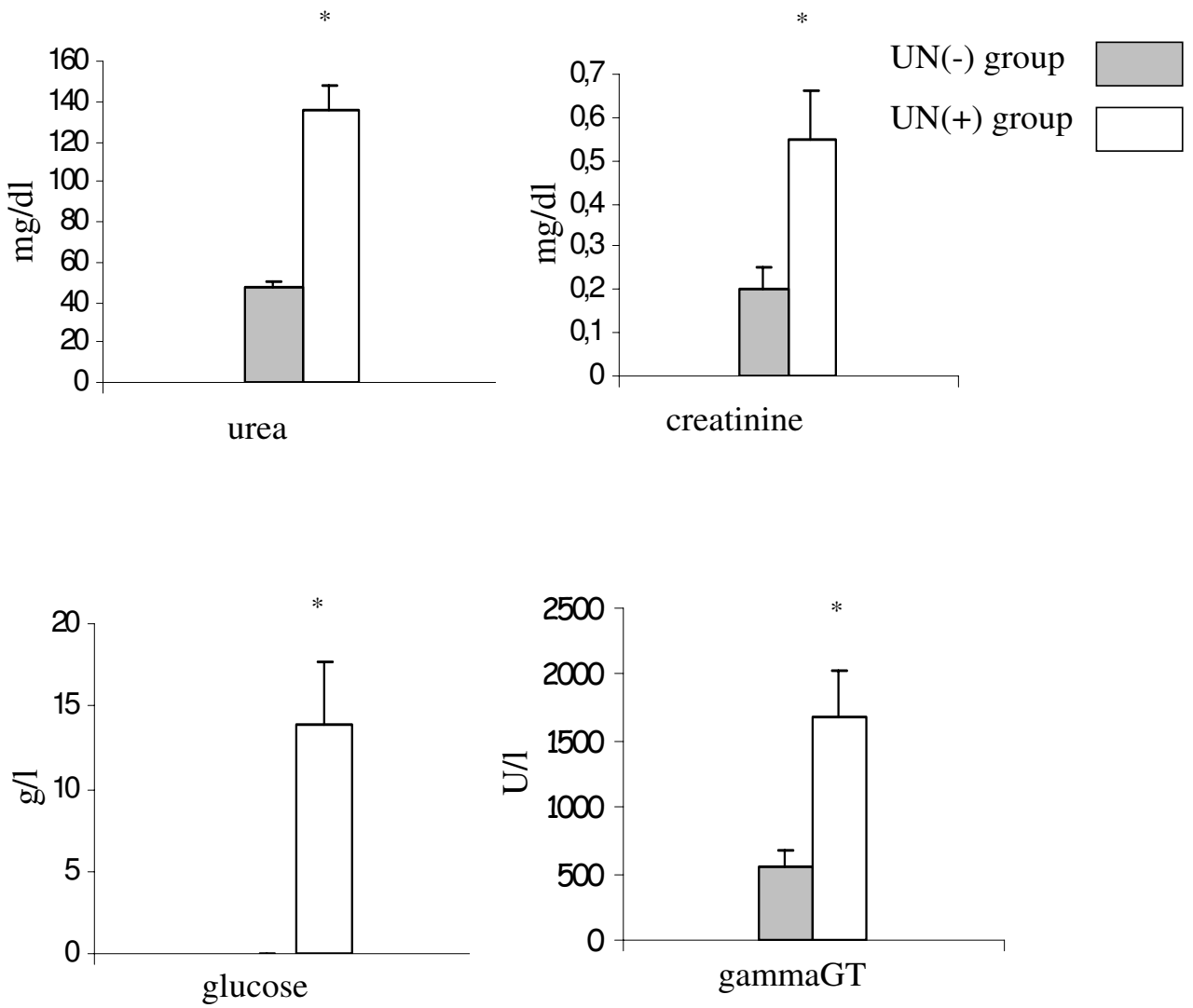

B

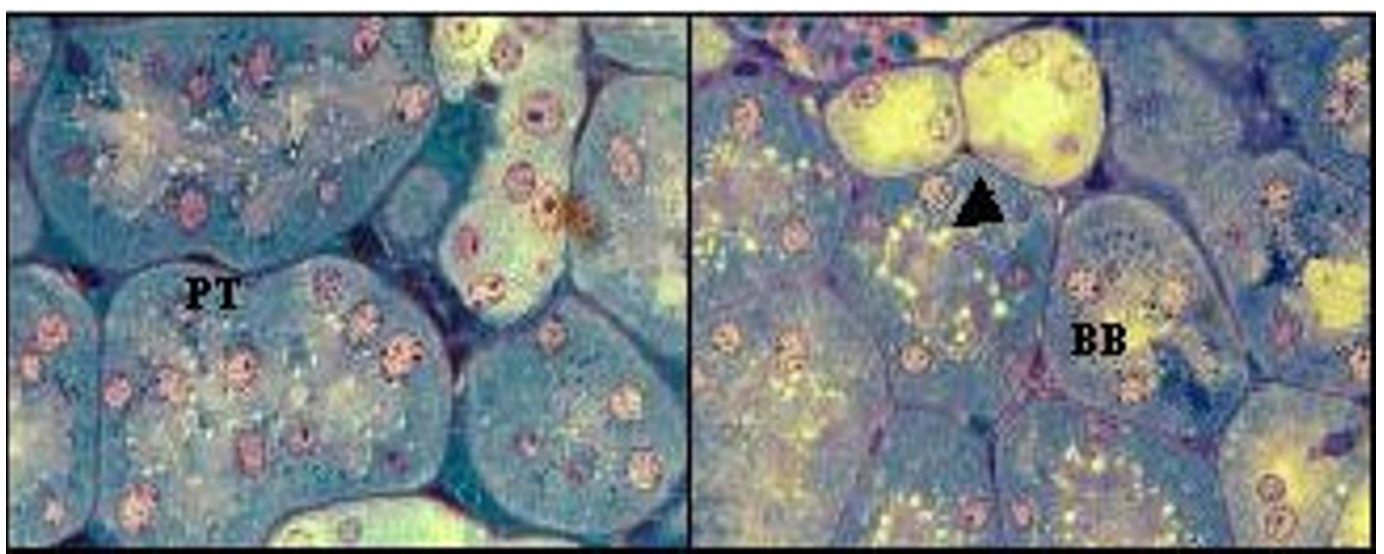

Figure I

Characterization of UN-induced ARF. (A) Influence of UN on renal function. Blood levels of urea and creatinine and urinary levels of glucose and $\gamma \mathrm{GT}$ are plotted. The bars represent the mean \pm SEM. ${ }^{*} \mathrm{p}<0.05$ vs control. (B) Light micrographs of renal tissue from UN(-) (left panel) and UN(+) (right panel) group given $5 \mathrm{mg} / \mathrm{kg} U N$ intraperitoneally. Proximal tubules (PT), sectioned transversely, are lined by high cuboidal or pyramidal epithelium. A slight loss in the brush border (BB), and large vacuoles (arrow) in proximal tubular cells in comparison with control group are depicted $(\times 40)$. 


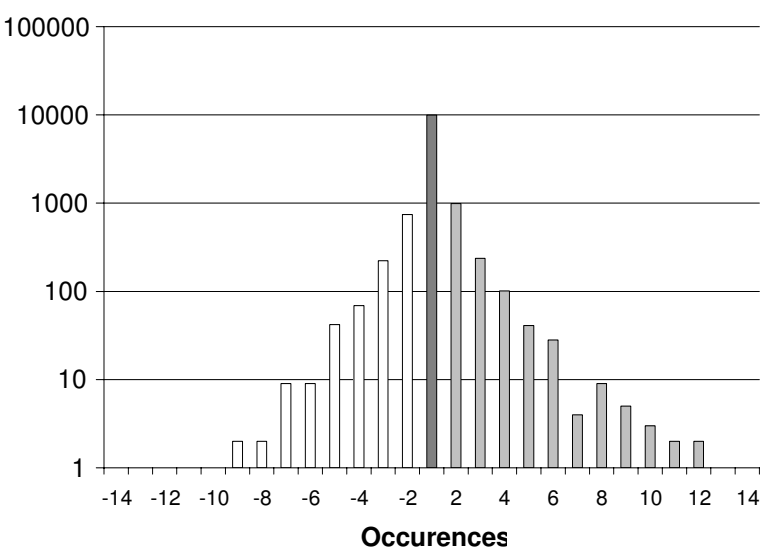

Figure 2

Summary of the SAGE data. The ratio of the number of occurrences for each given unique tag in both libraries (UN $(-)$ and UN (+)) has been calculated. Tags have been grouped according to their expression ratio (X-Axis). The frequency (Y-Axis) plot of this ratio shows a Gaussian distribution.

assigned to RIKEN sequence in the UniGene database. Monte Carlo simulations were used to determine the statistical significance of differentially expressed genes from both libraries (figure 2). As expected, the expression level was unmodified after UN injection for the majority of transcripts. Interestingly, 224 transcripts were significantly over-expressed (116) or under-expressed (108) in $\mathrm{UN}(+)$ animals (listed in table 3 ). After exclusion of tags matching mitochondrial sequences, and those with multiple and non-reliable matches, only tags with a significant expression change ( $\mathrm{p}$-values $<0.05$ ) were retained and arbitrarily grouped according to their function. SAGE analysis revealed an overexpression of genes related to the release of inflammatory mediators, such as the secreted phosphoprotein 1 (Spp1 or Opn 7/104), Umod (which encodes for the Tamm-Horsfall protein, 23/69), lectin galactose binding (gal-3, 1/13), tumor necrosis factor alpha-induced protein $(12 / 21)$ and Tctp (listed as translationally regulated transcript, 149/263) gene. Many genes involved in signaling were down-regulated such as hormonal receptors (growth hormone receptor, 15/3; parathyroid hormone receptor, 17/8) and transcripts encoding for chaperone proteins including heat shock $70 \mathrm{kD}$ protein 8 (Hsp70,52/29) and heat shock protein, $60 \mathrm{kDa} \mathrm{(13/}$ 4). Igfbp7 (45/85), also known as Igfbp-rP1/mac25 was found to be increased. The UN-induced transcripts mainly consist of gene encoding proteins associated with lipid metabolism (hydroxysteroid dehydrogenase, 25/10 and alcohol dehydrogenase, 7/1), amino acid metabolism (glutamate dehydrogenase, 4/16 and $O d c, 53 / 14$ ) and carbohydrate metabolism (fructose bisphosphate, 25/8; glucose phosphate isomerase, 0/6). UN exposure also increased the expression of a number of genes related to oxidative process and detoxification, including cytochrome P450 (Cyp4b1, 16/7) that catalyses the oxidation of a wide variety of substrates [29]. Other enzymes, such as peroxiredoxin $1(29 / 15)$, Sod1 $(19 / 6)$, peroxiredoxin 2 $(1 / 8)$, thioredoxin-like $2(2 / 9)$, ferritin light chain (32/ $62)$ were significantly under- or overexpressed. We also observed down-regulation of genes related with ion transporters including solute carrier family 22 (organic cation transporter)-like2 (57/23) and 34 (sodium phosphate), member1 (23/8) according with previous studies [29]. Numerous transcripts encoding for ribosomal proteins were up-regulated, such as Fau gene that encodes an ubiquitin-like protein fused to the ribosomal S30 protein (the cellular homolog of the fox sequence of the Finkel-BiskisReilly murine sarcoma virus (FBR-MuSV) [30], L9 (21/ 52), L19 (77/131), Large P1 (55/124) and S29 (37/81).

\section{Confirmation of SAGE data}

Real-time quantitative $P C R$ analysis

We performed real-time quantitative PCR analyses of eleven selected genes to confirm the differential expression observed by SAGE. Kap was chosen because of its abundance in normal $(1.4 \%)$ and in contaminated $(0.38 \%)$ kidney. Opn was chosen because we observed an increase in its expression rate in UN-ARF and it had been previously related to uranyl acetate-induced ARF [31]. Umod was chosen as it was increased in our SAGE data while it was previously reported to decrease in ARF [16]. Sod1, Odc, Calmodulin 2 (Calm2), Solute carrier family 34 (sodium phosphate) member1 ( $\mathrm{NaPi}-\mathrm{II}$ ) and Ferritin light chain 1 (Ftl1) were chosen as they were modified in ARF $[3,17,29,32]$. Results for all these transcripts corroborated the expression differences observed in our SAGE analysis (Figure 3A). Tctp, Igfbp7 and Rps29 were included in the RT PCR analysis since they were observed to vary in ARF for the first time in our study. Real-time confirmed the SAGE results, as it showed an increase in PCR expression of $O p n$, Umod, Ftl1, Calm2, Tctp, Igfbp7 and Rps29 and a decrease in expression of kap, NaPi-II, Odc and Sod in ARF induced by UN.

\section{Western blotting}

To determine whether the gene expression changes were apparent at the protein level, we performed Western blotting experiments. The choice of the selected protein depends on the interest of the protein and the ability to obtain certain antibodies. The protein products of three genes with increased expression level (Gal-3, IGFBP7 and TCTP) and one with decreased expression level (ODC) were selected. Expression level was evaluated using $\beta$-actin gene as reference gene. Immunoblot analysis confirmed the accuracy of the differences in expression level observed in our SAGE analysis (Figure 3B). 
Table 3: List of tags with significant variation in expression level induced by UN injection $(p<0.05)$. The table includes their frequency and their relevant accession number.

\begin{tabular}{|c|c|c|c|c|c|c|}
\hline \multirow[t]{2}{*}{ Tag sequence } & \multicolumn{2}{|c|}{ Count } & \multirow[t]{3}{*}{ Gene name } & \multirow{3}{*}{$\begin{array}{l}\text { Accession } \\
\text { No. }\end{array}$} & \multirow{3}{*}{$\begin{array}{c}\text { Regulation } \\
\text { (up: +, down: -) }\end{array}$} & \multirow[t]{2}{*}{ Gene symbol } \\
\hline & UN- & UN+ & & & & \\
\hline \multicolumn{4}{|l|}{ Apoptosis } & & & \\
\hline TGACACAGGA & 4 & 0 & $\begin{array}{l}\text { cell death-inducing DNA fragmentation factor, alpha subunit- } \\
\text { like effector B }\end{array}$ & NM 009894 & - & Cideb \\
\hline TAGGGCAATC & 2 & 12 & SMT3 (supressor of mif two, 3) homolog 2, pseudogene 4 & & + & Smt3 h2-ps 4 \\
\hline \multicolumn{7}{|c|}{ Amino acid metabolism } \\
\hline ATTAACTTGG & 4 & 16 & glutamate dehydrogenase & NM 008133 & + & Glud \\
\hline ATACTAACGT & 53 & 14 & ornithine decarboxylase, structural & NM 013614 & - & Odc \\
\hline \multicolumn{7}{|c|}{ Carbohydrate metabolism } \\
\hline TGGATGCCTT & 7 & 1 & alcohol dehydrogenase I, complex & NM 007409 & - & Adhl \\
\hline TGGATCTCTG & 5 & 0 & carbonic anhydrase 4 & NM 007607 & - & Car4 \\
\hline CTATAATGCC & 25 & 8 & fructose bisphosphatase I & NM 019395 & - & Fbpl \\
\hline TTGTTCTGAC & 0 & 6 & glucose phosphate isomerase I complex & NM 008155 & + & Gpi \\
\hline CAGTTTGTAA & 4 & 0 & pyruvate dehydrogenase EI alpha I & NM 008810 & - & Pdahal \\
\hline ATAAGGGATT & 0 & 6 & UDP-galactose translocator 2 & NM_016752 & + & Ugalt2 \\
\hline \multicolumn{7}{|l|}{ Cell adhesion } \\
\hline GAAGAAAGGG & 10 & 1 & platelet/endothelial cell adhesion molecule & NM 008816 & - & Pecam \\
\hline \multicolumn{7}{|c|}{ Cell cycle/mitosis } \\
\hline GCGAGGGAGC & 4 & 0 & $\operatorname{dim} I$ (S. pombe) & NM 025299 & - & Dim-pending \\
\hline TGCTGCCATT & 0 & 6 & tubulin alpha 6 & NM 009448 & + & Tubab \\
\hline \multicolumn{7}{|l|}{ Homeostasis } \\
\hline CCCTGGGTTC & 32 & 62 & ferritin light chain I & NM 010240 & + & Ftll \\
\hline \multicolumn{7}{|c|}{ Immunity and defense } \\
\hline \multicolumn{7}{|c|}{ Immunity } \\
\hline TTATGGAAT & 0 & 7 & CD24a antigen & NM 009846 & + & $C d 24 a$ \\
\hline GTTCAAGTGA & 1 & 9 & la-associated invariant chain $\mathrm{Ag}$ CD74 classe II & $\overline{N M 010545}$ & + & li/CD74 \\
\hline TAGGGAATGG & 0 & 5 & interferon-induced protein with tetratricopeptide repeats 3 & NM_01050I & + & Ifit3 \\
\hline CTGAGAGATA & 1 & 13 & lectin, galactose binding, soluble 3 & $\overline{N M 010705}$ & + & Lgals3/Gal-3 \\
\hline ATTGGGGGAG & 6 & 18 & osteoclast inhibitory lectin & NM 053109 & + & ocil-pending \\
\hline CAAACACCGT & 7 & 104 & secreted phosphoprotein I & NM 009263 & + & Sppl, Opn \\
\hline TGGGTTGTCT & 149 & 263 & translationally regulated transcript $(2 \mathrm{l} \mathrm{kDa})$, & NM 009429 & + & $\begin{array}{l}\text { Trt, Tptl, } \\
\quad \text { Tctp }\end{array}$ \\
\hline TTTTATGTTT & 12 & 21 & tumor necrosis factor, alpha-induced protein I (endothelial) & NM 009395 & + & Tnfaip I \\
\hline TATACATCCA & 23 & 69 & uromodulin & NM_009470 & + & Umod \\
\hline \multicolumn{7}{|c|}{ Antioxidant and free radical removal } \\
\hline СТАТССТСТС & 419 & 537 & glutathione peroxidase 3 & NM 008161 & + & $G p \times 3$ \\
\hline ATGTGGTGTG & 29 & 15 & peroxiredoxin I & NM 011034 & - & $\operatorname{PrdxI}$ \\
\hline GGTGAGCCTG & 1 & 8 & peroxiredoxin 2 & NM 011563 & + & $\operatorname{Prd} 22$ \\
\hline TATCTGTGCA & 28 & 16 & selenoprotein $\mathrm{P}$, plasma, I & NM 009155 & - & Seppl \\
\hline AGAAACAAGA & 19 & 6 & superoxide dismutase I, soluble & $\underline{X M \quad 128337}$ & - & Sodl \\
\hline TTGCTTCTAT & 12 & 0 & thioether S-methyltransferase & NM 009349 & - & Temt \\
\hline CTACGTTCTC & 2 & 9 & thioredoxin-like 2 & NM 023140 & + & $T x n / 2$ \\
\hline \multicolumn{7}{|c|}{ Lipid fatty acid and steroid metabolism } \\
\hline AGCCCTCGGA & 5 & 0 & acetyl-Coenzyme A dehydrogenase, short chain & NM 007383 & - & Acads \\
\hline TTAAGACCTG & 10 & 21 & crystallin, zeta & NM 009968 & + & CryZ \\
\hline TAGAATAAAC & 4 & 0 & cytochrome P450, 2d9 & $\overline{N M 080006}$ & - & Сур 2d9 \\
\hline TGTGTGGAAT & 16 & 7 & cytochrome P450, subfamily IV B, polypeptide I & NM 007823 & - & Сур $4 b$ l \\
\hline TGCCAACGCA & 25 & 10 & hydroxysteroid dehydrogenase- 4 & NM 008292 & - & Hsdl $7 b 4$ \\
\hline AATTTAATTA & 5 & 0 & phytanoyl-CoA hydroxylase & NM 010726 & - & Phyh \\
\hline \multicolumn{7}{|c|}{ Muscle contraction } \\
\hline TGCAGTCATC & 8 & 1 & transgelin & NM 011526 & - & Tagln \\
\hline CTCTGGGGCT & 0 & 6 & transgelin 2 & NM 178598 & + & Tagln2 \\
\hline \multicolumn{7}{|c|}{ Nucleoside, nucleotide and nucleic acid metabolism } \\
\hline CTAGATTGCG & 4 & 0 & ectonucleoside triphosphate diphosphohydrolase 5 & NM 007647 & - & Entpd5 \\
\hline AAGAAACCAG & 33 & 16 & $\begin{array}{l}\text { expressed in non-metastatic cells 2, protein (NM23B) } \\
\text { (nucleoside diphosphate kinase) }\end{array}$ & NM 008705 & - & Nme2 \\
\hline GTGTAATAAG & 2 & 8 & heterogeneous nuclear ribonucleoprotein $\mathrm{A} 2 / \mathrm{BI}$ & NM 016806 & + & Hnrpa2bl \\
\hline GGGAGCGAAA & 16 & 8 & inhibitor of DNA binding 2 & NM 010496 & - & $1 d b 2$ \\
\hline
\end{tabular}


Table 3: List of tags with significant variation in expression level induced by UN injection $(p<0.05)$. The table includes their frequency and their relevant accession number. (Continued)

\begin{tabular}{|c|c|c|c|c|c|c|}
\hline TACTGTCCTG & 5 & 0 & RNA polymerase $\mathrm{I}-3$ (16 kDa subunit) & NM 009087 & - & Rpol-3 \\
\hline \multicolumn{7}{|l|}{ Oxydoreductase } \\
\hline AATGGCTAGC & 13 & 5 & cytochrome c, somatic & NM 025567 & - & Cycs \\
\hline \multicolumn{7}{|c|}{ Protein metabolism and modification } \\
\hline \multicolumn{7}{|l|}{ Amino acid activation } \\
\hline GCCAATAGTG & 0 & 5 & endothelial monocyte activating polypeptide 2 & NM 007926 & - & Emap2/Scyel \\
\hline \multicolumn{7}{|l|}{ Protein biosynthesis } \\
\hline ТСАСССААТА & 64 & 44 & eukaryotic translation elongation factor 2 & NM 007907 & - & Eef2 \\
\hline CTAATAAAGC & 34 & 68 & $\begin{array}{l}\text { Finkel-Biskis-Reilly murine sarcoma virus (FBR-MuSV) } \\
\text { ubiquitously expressed (fox derived) }\end{array}$ & NM 007990 & + & Fau \\
\hline AGATCTATAC & 13 & 4 & ribosomal protein L7 & NM 011291 & - & Rpl7 \\
\hline AACAATTTG & 21 & 52 & ribosomal protein L9 & NM 011292 & + & Rp/9 \\
\hline GGCAAGCCCC & 20 & 42 & ribosomal protein LIOA & NM 011287 & + & RpllOa \\
\hline TGGATCAGTC & 77 & $|3|$ & ribosomal protein LI9 & NM 009078 & + & Rpll9 \\
\hline ATTCTCCAGT & 13 & 36 & ribosomal protein L23 & NM 022891 & + & Rp/23 \\
\hline CCCACAAGGT & 16 & 6 & ribosomal protein L27 & NM 011289 & - & Rp/27 \\
\hline GGCTTCGGTC & 55 & 124 & ribosomal protein, large, PI & NM 018853 & + & RplpI \\
\hline TGTAGTGTAA & 26 & 52 & ribosomal protein $\mathrm{S} 8$ & NM 009098 & + & Rps8 \\
\hline TGGCCCAAA & 2 & 12 & ribosomal protein SI6 & NM 013647 & + & Rps I6 \\
\hline GCCTTTATGA & 24 & 14 & ribosomal protein S24 & NM 011297 & + & Rps24 \\
\hline TAAAGAGGCC & 21 & 48 & ribosomal protein S26 & NM 013765 & + & Rps26 \\
\hline CTAGTCTTTG & 35 & 81 & ribosomal protein S29 & NM 009093 & + & Rps29 \\
\hline \multicolumn{7}{|l|}{ Protein folding } \\
\hline TAACAGTTGT & 5 & 16 & calnexin & NM 007597 & + & Canx \\
\hline GATTGTCAAA & 1 & II & FK506 binding protein $3(25$ kD) & NM 013902 & + & Fkbp3 \\
\hline AGAGTTCAGA & 13 & 4 & heat shock protein, $60 \mathrm{kDa}$ & NM 010477 & - & $\begin{array}{l}\text { HspdII } \\
\text { Hsp60 }\end{array}$ \\
\hline GAATAATAAA & 52 & 29 & heat shock $70 \mathrm{kD}$ protein 8 & NM 031165 & - & $\begin{array}{l}\text { Hspa8/ } \\
\text { Hsp73 }\end{array}$ \\
\hline \multicolumn{7}{|l|}{ Proteolysis } \\
\hline CCTTGCTCAA & II & 27 & cystatin C & NM 009976 & + & Cst3 \\
\hline GAGAGTGTGA & 13 & 5 & kidney-derived aspartic protease-like protein & NM 008437 & - & Kdap \\
\hline ACCATTATAA & 14 & 7 & lysosomal membrane glycoprotein 2 & NM 010685 & - & Lamp2 \\
\hline TAGCTTCCTC & 15 & 37 & sequestosome I & NM 011018 & + & Sqstm I/p62 \\
\hline TGACCCCGGG & 51 & 88 & ubiquitin $\mathrm{A}-52$ residue ribosomal protein fusion product I & NM 019883 & + & Uba52 \\
\hline CAGATCTTTG & 6 & 19 & ubiquitin $\mathrm{C}$ & NM 145578 & + & Ubc \\
\hline \multicolumn{7}{|l|}{ Translation regulation } \\
\hline TGAAATACTT & 31 & 15 & heat-responsive protein 12 & NM 008287 & - & Hrsp/2 \\
\hline \multicolumn{7}{|c|}{ Signal transduction system, receptor } \\
\hline GCACAACTTG & 3 & 15 & calmodulin 2 & NM 007589 & + & Calm2 \\
\hline GGCTGTTGAA & 0 & 10 & cysteine rich protein & NM 007791 & + & csrpl \\
\hline CATACGCATA & 15 & 3 & growth hormone receptor & NM 010284 & - & Ghr \\
\hline GCTGCAGTTG & 0 & 5 & guanine nucleotide binding protein, beta 2 , related sequence & NM $008 \mid 43$ & + & Gnb2-rsI \\
\hline AGAGACAAGG & 23 & 4 & N-myc downstream regulated I & NM 006096 & - & Ndrgl \\
\hline ATCTCCTAGC & 0 & 10 & matrix gamma-carboxyglutamate (gla) protein & NM 008597 & + & Mglap \\
\hline AGCACTTTGC & 1 & 10 & $\begin{array}{l}\text { Mus musculus, serine threonine kinase pim3, clone } \\
\text { MGC:27707 IMAGE: } 4924687\end{array}$ & & & + \\
\hline GGCAGATGGA & 17 & 8 & parathyroid hormone receptor, PTH R & NM 011199 & - & Pthr \\
\hline TGGGGAAGAG & I & 8 & phosphatidylethanolamine binding protein & NM 018858 & + & $P b p$ \\
\hline TAACCAATCA & 7 & 19 & RAB5C & NM 004583 & + & Rab5c \\
\hline AAAATTGCTT & 14 & 0 & $\begin{array}{l}\text { tyrosine } 3 \text {-monooxygenase/tryptophan } 5 \text {-monooxygenase } \\
\text { activation protein, zeta polypeptide }\end{array}$ & NM 011740 & - & Ywhaz \\
\hline \multicolumn{7}{|l|}{ Transport } \\
\hline \multicolumn{7}{|l|}{ Electron transport } \\
\hline GCTTTGAATG & 40 & 19 & ATPase inhibitor & NM 007512 & - & Atpi \\
\hline GAAGGAAACC & 4 & 0 & $\begin{array}{l}\text { ATP synthase, } \mathrm{H}+\text { transporting mitochondrial FI complex, } \\
\text { beta subunit }\end{array}$ & $\underline{N M} 016774$ & - & Atp5b \\
\hline GCATACGGC & 5 & 12 & $\begin{array}{l}\text { ATP synthase, } \mathrm{H}+\text { transporting, mitochondrial FIF0 } \\
\text { complex, subunit e }\end{array}$ & $\underline{N M} 007507$ & + & Atp5k \\
\hline TTATGAAATG & 31 & 58 & NADH dehydrogenase (ubiquinone) I alpha subcomplex, I & NM 019443 & + & Ndufal \\
\hline CTTGCAAGTG & 40 & 26 & NADH dehydrogenase (ubiquinone) I beta subcomplex, 9 & NM 023172 & - & Ndufb9 \\
\hline
\end{tabular}


Table 3: List of tags with significant variation in expression level induced by UN injection $(p<0.05)$. The table includes their frequency and their relevant accession number. (Continued)

\begin{tabular}{|c|c|c|c|c|c|c|}
\hline ATGGGATTGA & 0 & 21 & glutamate receptor, ionotropic, kainate I & NM 146072 & + & Grik I \\
\hline AGAGGCTACA & 4 & 0 & solute carrier family $2 \mathrm{I}$ (organic anion transporter)mb I & NM 013797 & - & Slc2lal \\
\hline GACACATACC & 57 & 23 & solute carrier family 22 (organic cation transporter)-like 2 & NM 009203 & - & Slc22al2 \\
\hline ACATTTCCAG & 5 & 0 & solute carrier family 27 (fatty acid transporter), mb 2 & NM 011978 & - & Slc27a2 \\
\hline TTGTGAGCCA & 23 & 8 & solute carrier family 34 (sodium phosphate), member I & NM 011392 & - & Slc34al \\
\hline \multicolumn{7}{|c|}{ Lipid and fatty acid transport } \\
\hline GCTCTGATAC & 5 & 0 & sterol carrier protein 2, liver & NM 138508 & - & Scp2 \\
\hline \multicolumn{7}{|l|}{ Others } \\
\hline GAACCTCTCC & 0 & 5 & amyotrophic lateral sclerosis 2 (juvenile) homolog (human) & NM 028717 & + & Als2 \\
\hline GAAGATCTAA & 5 & 0 & $\begin{array}{l}\text { DNA segment, Chr 10, Johns Hopkins University } 81 \\
\text { expressed }\end{array}$ & NM_13860I & - & DIOjhu8le \\
\hline GTCGTGCCAT & 59 & 12 & DNA segment, Chr 7, Roswell Park 2 complex, expressed & NM 033080 & - & D7rp2e \\
\hline TCATTCTCCA & 9 & 0 & erythrocyte protein band 4.1 -like $4 \mathrm{a}$ & NM 013512 & - & Epb4. II4a \\
\hline CTCCTGCAGC & 18 & 41 & esterase 10 & NM 016903 & + & Es 10 \\
\hline CTTCTTTCTG & 0 & 7 & growth arrest specific 6 & NM 019521 & + & Gas6 \\
\hline TAGCTTTAAA & 45 & 85 & insulin-like growth factor binding protein 7 & NM 008048 & + & $\operatorname{lgfbp} 7$ \\
\hline GACTTCACGC & 283 & 91 & kidney androgen regulated protein & NM 010594 & - & Kap \\
\hline GCATAGAAAT & 22 & 8 & kidney-specific membrane protein & NM 020626 & - & Nx/7-pending \\
\hline TAACTGACAA & 4 & 20 & metallothionein 2 & NM 008630 & + & Mt2 \\
\hline TGACCACGGG & I & 9 & myeloid differentiation primary response gene 88 & NM 010851 & + & Myd88 \\
\hline GCCCCAATAA & 20 & 12 & phosphatidylcholine transfer protein-like & NM 019990 & - & $\begin{array}{c}\text { Pctpll } \\
\text { Sdccagg28 }\end{array}$ \\
\hline TAATACTCAA & 73 & 49 & upregulated during skeletal muscle growth 5 & NM 023211 & - & Usmg5 \\
\hline
\end{tabular}

\section{Discussion}

The kidney is a complex organ consisting of well-defined components that function in a highly coordinated fashion. When a segment of the functional unit of the kidney is altered, ARF may occur. Tubules are the most frequently damaged area in ARF. Some mechanisms responsible for tubular damage are already well described such as inflammation, apoptosis and oxidative stress. However, the molecular events involved in the cellular response to renal injury are not completely elucidated, neither those participating in inflammation, apoptosis and oxidative stress, nor those participating in other cell metabolisms that might also be involved in ARF. To obtain a holistic view of the molecular processes involved in nephrotoxic ARF, we studied the changes in the transcriptome of kidney after UN treatment.

Genome level transcriptional profiling of a given cell, tissue, or organ provides a map of interconnected molecular pathways and reflects coordinated response of their various components to a given physiological condition. Because Gene chips only measure the expression of genes represented on the chip in contrast to SAGE, in which the expression profile of the complete transcriptome can be mapped, we have used SAGE approach to identify renal molecular effects of acute exposure to uranium in mice. SAGE is a high-throughput method for quantitative evaluation of global gene expression [33]. Similarly to microarray technology, SAGE can be used to evaluate genomewide transcriptional response of a given-cell, tissue, or organ to environmental stimuli. Nonetheless, whereas large numbers of samples may be analyzed more efficiently by using the microarray technique, SAGE does not depend on a priori gene knowledge and thus represents a truly unbiased technique.

More than 200 transcripts out of the $>14,500$ unique transcripts observed were differentially expressed in $\mathrm{UN}(+)$ and in UN(-) animals. The differentially regulated genes could be distributed into three groups: group 1 including those genes that had been previously identified to participate in all forms of ARF, group 2 which encloses those genes participating in ARF but not previously related to the UN-induced form of ARF, and group 3 that includes those genes that had not been previously suspected to participate in any form of ARF. All three groups of genes are relevant in our study, since the group 1 genes validate our system in relation to previous reports (they represent an appropriate internal positive control). Group 2 genes demonstrate that some of the molecules participating in UN-induced ARF are shared with other forms of ARF. Finally, group 3 genes provide evidence for involvement in ARF of newly identified genes.

Although, the genes identified by SAGE are informative on the possible endeavors that may be taken to extend our research on the understanding of UN-related ARF, supplementary studies with other techniques should follow. However, to choose the ways to focus our future efforts, it is capital to evaluate each gene that has been identified according to the metabolic systems it participates and the relevance it may have on the events observed in ARF. Fol- 
lowing, we include a brief analysis of those genes retaining our attention on these grounds.

Among the group 1 genes, Opn is the most differentially expressed gene (15-fold increase). Osteopontin is involved in inflammation [6] and in proximal tubule regeneration [31], and has been proposed as a marker for renal injury [34]. Also among the genes of group 1, Cu, $\mathrm{Zn}$-SOD, a key enzyme against oxidative stress, was underexpressed in UN-induced ARF, in agreement with previous data [3]. This description underlies the poorly studied molecular mechanism related to UN-induced ARF.

Gal-3, a gene of group 2, was up-regulated (1/13). Gal-3 is a pro-inflammatory molecule [35] containing in its sequence the asparagine-tryptophan-glycine-arginine motif, highly conserved in the BH1 domain of the Bcl-2, a well characterized suppressor of apoptosis [36]. A decrease in apoptosis is known to be related to an increase in mitochondrial integrity, a diminution in cytochrome $\mathrm{C}$ release, and caspase activation; three features that have been described for Gal-3 [36]. However, the mechanisms by which Gal-3 participates in UN-induced ARF are not known. Exploring this point seems of interest in ARF. Among the genes that had not been previously related to UN-ARF, we also noted metallothionein 2(MT-2) and Calm 2, known to be up-regulated after a heavy metal contamination $[37,38]$. The latter, a putative calcium transporter, is essential for mitotic progression and its upregulation may be a response to possible direct metal effect [37]. The responses of MT-2 are not surprising, as it is known to participate in stress response. Despite many decades of research, the present physiologic function of MT has not been elucidated. However, some suggested functions attributed to this protein include detoxification of nonessential heavy metals (cadmium and mercury), homeostasis of zinc and copper, metal transfer, free-radical scavenger, and metal storage [38]. Another interesting gene of this group 2 is Umod. It encodes for Tamm-Horsfall protein and has been reported to be down-regulated in ischemia-induced ARF [16]. Our SAGE analysis surprisingly showed an up-regulation of Umod expression. This increase was also confirmed by our RT-PCR studies, suggesting that THP behaves differently in ischemia- and UNinduced ARF. THP has been related to inflammation and showed to participate in hyperuricemic nephropathy as well as in medullary cystic disease [39]. In addition, an up-regulation of UMOD has been observed in the progression of nephrolithiasis [40]. The similarity between renal stone formation and UN crystal deposition, as well as the putative role of THP in these forms of ARF certainly deserves further study. Another interesting family of genes is constituted by the NaPi-II transporters, which are mainly expressed on the brush border of PT and modulate tubular reabsorption of inorganic phosphate [29]. Their renal expression was decreased in $\mathrm{UN}(+)$ animals, in keeping with the tubular damage and increased $\gamma \mathrm{GT}$ urinary levels. Also among the genes of group 2, ODC, the rate-limiting enzyme of polyamine biosynthesis, was down-regulated in UN-induced ARF. Studying a model of chronic renal failure, Fleck et al. also observed a decrease in $O d c$ expression level 10 weeks after a single injection of UN [41]. We confirmed this observation following UN long-term exposure in mice [18]. Kramer et al. have obtained a depletion of polyamine pool using a specific biosynthetic enzyme inhibitor of ODC, resulting in p21mediated G1 cell cycle arrest [42]. Therefore, the decrease in Odc mRNA level might be related to an arrest of cell cycle following UN treatment. The putative role of ODC and the participation of the cell cycle on UN induced ARF also appear important. Finally in this group 2, we observed a decrease in the expression level of Kap gene. While its expression in S1 and S2 segments is androgen dependent, no androgen is required for KAP expression in S3 segment. KAP is then observed in S3 of female and castrated males [43] and has been used as a S3 marker [26]. It participates in thyroid and growth hormone/insulinlike growth factor-1 axis, known to be involved in other forms of ARF.

The most novel part of our results concern group 3 genes: those that had not been previously related to ARF. Three genes were identified Rps29, Igfbp7 and Tctp and all of them are markedly up-regulated in UN induced ARF. RPS29 is a potent apoptosis-inducing agent [44], and its over expression further supports the participation of apoptosis in UN-induced ARF. IGFBP7 is a potential transcription factor [45] with a variable distribution along the renal tubular epithelium. It could be involved in the regulation of cell growth and differentiation [46]. In addition, it might have a tumor suppressor activity through the induction of cell senescence [46]. Therefore, the study of the participation of this protein in UN-induced ARF is also of interest. Finally, TCTP is a protein usually found in the cytoplasm of both normal and tumor cells lines. This finding provide additional evidence for an up-regulation of TCTP in animals treated by heavy metal exposure [47]. Interestingly, we also observed an over-expression after UN long-term ingestion [18]. However, it is the first time that enhanced tctp expression results from acute UN exposure. TCTP has been previously characterized as an inflammatory molecule with an IgE-dependent histamine-releasing capacity [48]. It was also described as an antiapoptotic protein [46]. TCTP, a tubulin-binding like protein is associated with microtubules in a cell cycle dependent manner [48] and is associated with components of the translational machinery [49]. Moreover, its expression is regulated by $\mathrm{Ca}^{2+}[48]$. Thus, TCTP is implicated in cell growth and differentiation, acute allergic response, apoptosis and other various processes $[48,49]$ 
A

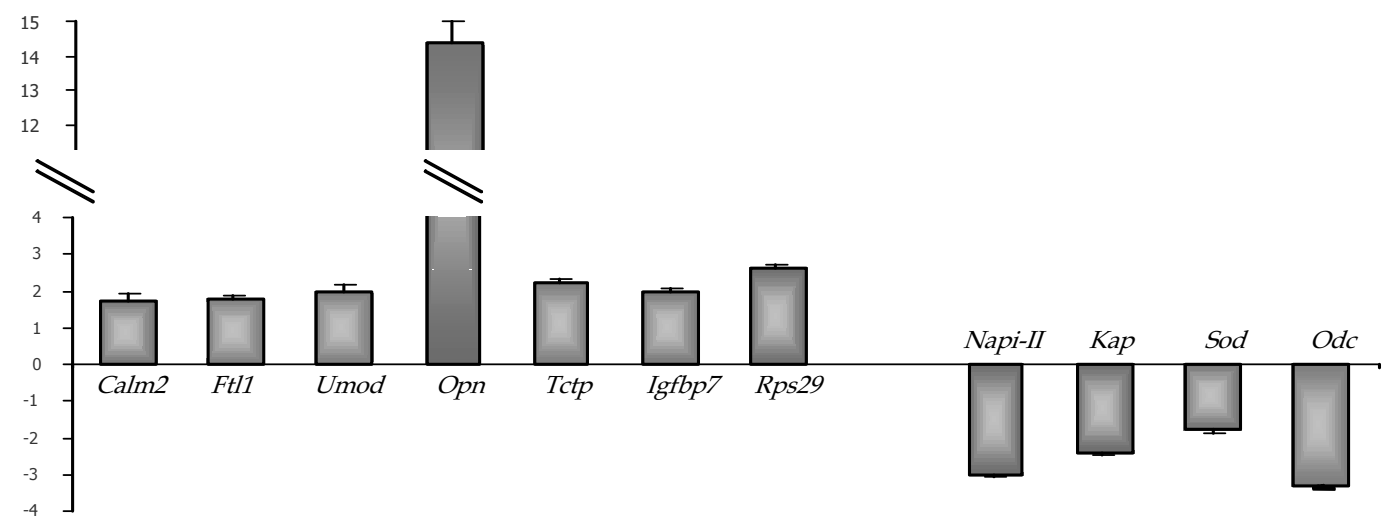

B

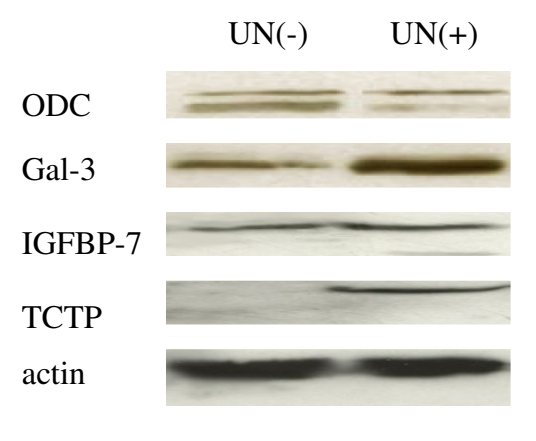

\section{Figure 3}

Confirmation of SAGE data. (A). Real-time RT-PCR analysis. The relative fold change of UN(+)/UN(-) is plotted. PCR analyses were performed on cDNA from UN(-) or UN(+) tissues. All values represent the mean \pm SEM. ${ }^{*} \mathrm{p}<0.05$ vs control. (B). Western blot analysis of ODC, TCTP, IGFBP7 and Gal-3 proteins in UN(-) and UN(+) tissues. Fifty micrograms of total cell protein were loaded per lane on a 10\% SDS-polyacrylamide gel, and ODC, TCTP, IGFBP7 and Gal-3 were detected by immunoblotting with antibodies against the respective proteins. As a control for proteins loading in SDS-PAGE, an anti- $\beta$-actin antibody was used.

and may be a central protein in the phenomena observed in UN-induced ARF. More work will be necessary to establish whether TCTP might be suitable as diagnostic tool or for other medical application in connection with renal failure.

\section{Conclusion}

Whereas the full potential of SAGE for gene expression profiling could not be exploited due to the difficulties in tag to gene assignment, one of the major strengths of SAGE is the electronic nature of the database, allowing further investigations and direct comparisons of libraries in silico by different investigators. Nevertheless, this first SAGE analysis lays the basis for furthers studies. Indeed, accumulation of additional data will increasingly facilitate the interpretation of results because bona fide tags will be distinguished from artifacts by being replicated and even polymorphic tags will eventually be defined and assigned to their corresponding transcripts. Despite these promising results, further investigations must be performed to increase the usefulness of transcript profiling in toxicology. A next step will be to address issues related to dose-response relationships and human exposure assessment. This will allow us to confirm whether observed gene expression changes are effectively indicative of toxic liabilities when standard parameters do not yet detect toxicity as previously reported in UN-long-term exposure [18].

In this report, we elegantly demonstrated that UNinduced renal injury is associated with dramatic alterations in gene expression profile, as presented on the 


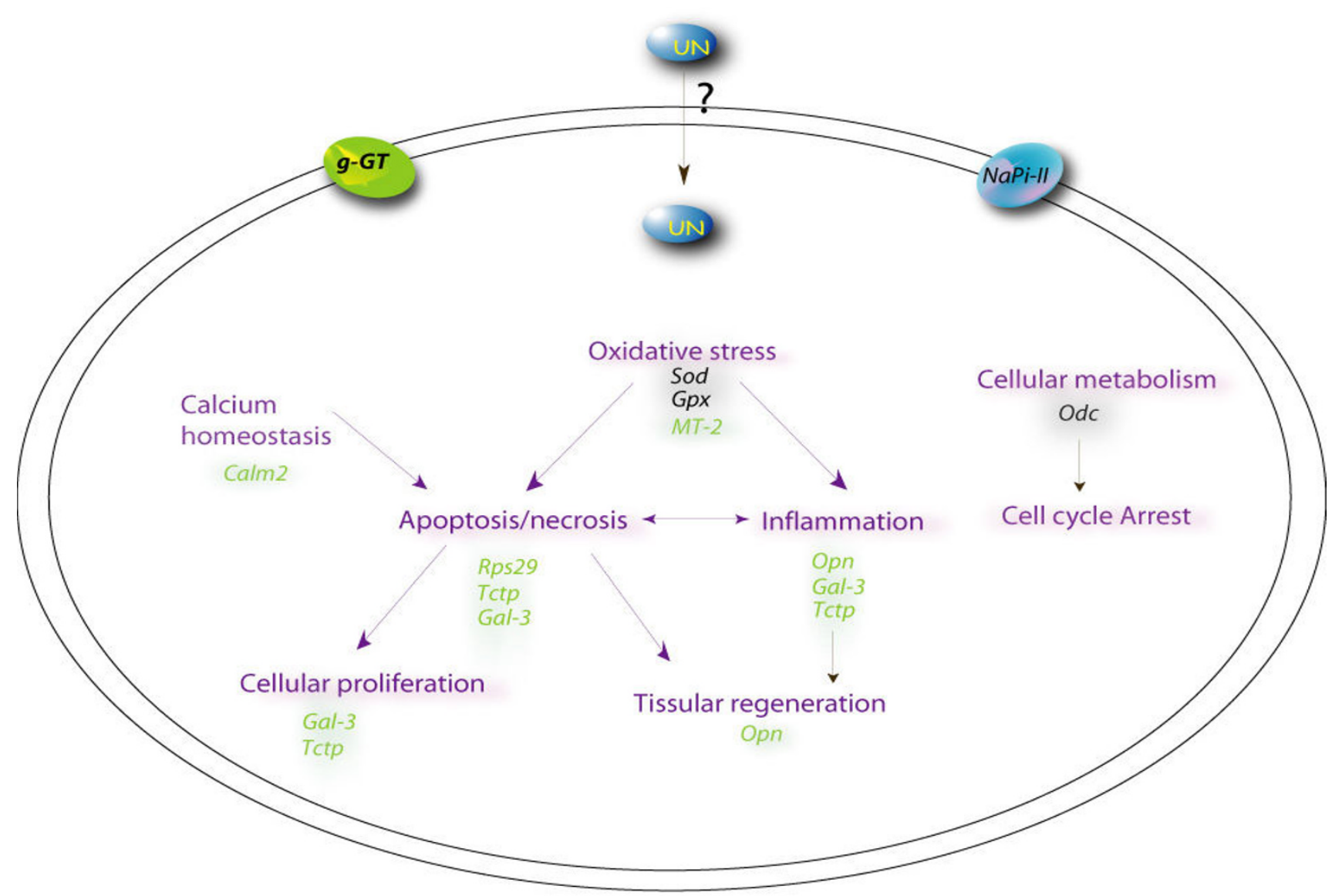

\section{Figure 4}

Putative cellular pathways of UN-mediated nephrotoxicity. The diagram depicts the putative pathways involved in UN-mediated toxicity. This schematic was assembled using the gene expression data from 2 days UN treatment and previous litterature. Up- or down-regulation is denoted by different colors (green and black, respectively). Mechanisms (in purple) such as oxidative stress, apoptosis, inflammation and perturbation of calcium homeostasis might contribute to uranium toxicity. Secondary compensatory mechanisms were evident as increases in tissue regeneration and cellular proliferation.

depicted drawing (figure 4). UN up- or down-regulates genes involved in inflammatory, in oxidative response, in protein and lipid metabolism, in androgenic response and in solute transporters. Changes in expression of a selected group of genes, known to participate in ischemic and toxic ARF (OPN and SOD) and also in genes known to be linked to ischemic or toxic ARF but not previously described in UN-induced ARF (KAP, UMOD, Calm2, Ftl1, $\mathrm{NaPi}-\mathrm{II}$ and ODC), were confirmed at both mRNA and protein level (Gal-3 and ODC). Our SAGE analysis, in addition to showing the global changes in transcriptome, enabled us to identify new genes associated to ARF (e.g. TCTP, IGBFP7 and Rps29). This finding of potential proor anti-apoptotic up-regulated transcripts by SAGE analysis was confirmed by quantitative RT-PCR and immunob- lot. Further global analyses of gene expression changes associated with different types of ARF will be necessary to define genes which are potential hallmarks of specific mechanisms of UN-renal injury and which are more general markers of renal damage. Apoptosis, cell cycle and inflammation appear as the main features in UN-induced ARF. Indeed, apoptosis has recently emerged as the major mechanism leading to early tubule cell death following ischemia-reperfusion injury and down-regulation of apoptosis may offer a novel therapeutic approach for the amelioration of ischemic or toxic renal injury. Further study of the genes implicated in these processes should shed light on our understanding of the physiopathology of toxic ARF; a mandatory step in identifying new markers and/or treatment targets of the disease. 


\section{Methods \\ Animals}

Twenty male C57 Bl/6J mice, weighing 25-30 g (Harlan, France) were housed in light controlled rooms with 12-h periods of light and darkness and free access to food and water. They were randomly divided into two groups: controls (UN(-)) and Uranyl nitrate-treated (UN(+)) mice.

\section{Uranyl nitrate-induced acute renal failure}

A single dose of $5 \mathrm{mg} / \mathrm{Kg}$ of Uranyl nitrate (Merck, France) in $0.9 \% \mathrm{NaCl}$, or the vehicle alone, was given intraperitoneally [1]. The animals were euthanized by ex-sanguination using cardiac puncture 48 hours after the injection to evaluate early renal injury [34]. As we did not perform a time-course, the time-point and concentration choices are based on prior knowledge $[1,34]$. Uranium residues were examined in samples of kidney using a kinetic phosphorescence analyzer (KPA) [50]. Serum creatinine and urea levels and urinary concentrations of glucose, gammaglutamyltranspeptidase $(\gamma \mathrm{GT})$ were measured by routine methods.

\section{Sample preparation}

The kidneys were either embedded in epon for morphological examination or snap-frozen in liquid nitrogen and then stored at $-70^{\circ} \mathrm{C}$ until further study.

\section{Preparation of kidney samples for morphological examination \\ Preparation}

Kidney specimens were cut into $1 \mathrm{~mm}$ cubes and fixed with 3\% gluteraldehyde in aqueous solution. Following post-fixation, the cubes were dehydrated in ascending grades of ethanol and absolute ethanol for 1 h30, infiltrated with propylene oxide and propylene oxide-epoxy resin, and finally embedded in epon.

\section{Morphology}

For light microscopy, $1 \mu \mathrm{m}$ sections were cut from tissue blocks using a Leica ultramicrotome. The sections were mounted on glass slides and stained with toluidine blue (1\%), basic fuchsine dye solution (1\%) and examined under a Zeiss optical microscope.

\section{Score}

Tubular injury was ranked according to tubular cells desquamation in grade 0 (normal tissue), grade 1, 2, 3, 4 (cells desquamation $<25,25-50,50-75,75-100 \%$ respectively).

\section{RNA isolation}

Total RNAs, extracted from the renal tissue using the RNA isolation mini kit (Qiagen, France) were pooled and stored at $-70^{\circ} \mathrm{C}$ until further study. The amount of total RNA was determined using a fluorescent nucleic acid stain
(RiboGreen RNA Quantitation kit, Molecular Probes). The quality of the RNA was evaluated by measuring the 260:280-nm ratios and confirmed by visualization of intact $18 \mathrm{~S}$ and $28 \mathrm{~S}$ RNA bands after agarose gel electrophoresis. For SAGE analysis, in both treated and control groups, an equal amount of kidneys extracted RNAs from each mouse was pooled into a single sample. In some selected instances, RNA from a single animal was analyzed by real-time RT-PCR.

\section{Analysis of gene expression}

Kidney libraries were generated from $50 \mu \mathrm{g}$ of total RNA using I-SAGE kit (Invitrogen, France) following the manufacturer's instructions [51], adapted from initial description [33], and previously described [18]. SAGE data for the libraries described here are available at Gene Expression Omnibus [52]; accession nos. GSM 24251 and GSM 24255). In Results section, tags occurrence were arbitrarily noted as follow: tags occurrence in UN(-)/tags occurrence in $\mathrm{UN}(+)$.

\section{Real-time RT-PCR}

Total RNAs $(1 \mu \mathrm{g})$ from $\mathrm{UN}(-)$ and $\mathrm{UN}(+)$ renal tissue (extracted as described above RNA isolation) were used to generate cDNA using M-MLV-RT (Invitrogen) according the manufacturer's conditions. Primers and probes specifically designed for selected cDNA using PRIMER EXPRESS software version 2.0 (PE, Applied Biosystems), are listed in table 2. The ABI PRISM 7000 sequence detection system was used for detected real-time RT-PCR products with the SYBR Green I assay according to recommendations of the manufacturer ( $\mathrm{PE}$, Applied Biosystems). For three cases, in which we encountered difficulties with the SYBR Green I assay, we used the TaqMan probe assays (table 2). Each PCR reaction was optimized to ensure that a single band of the appropriate size was amplified and that no bands corresponding to genomic DNA amplification or primer-dimer pairs were present. The PCR cycling conditions were performed for all samples as follows: $50^{\circ} \mathrm{C}, 2$ min for AmpErase UNG incubation, $95^{\circ} \mathrm{C}, 10 \mathrm{~min}$ for AmpliTaq Gold activation, and 40 cycles for the melting $\left(95^{\circ} \mathrm{C}, 15 \mathrm{~s}\right)$ and annealing/extension $\left(60^{\circ} \mathrm{C}\right.$ for $\left.1 \mathrm{~min}\right)$ steps. PCR reactions for each template were done in triplicate in 96-well plates. The comparative $\Delta \Delta \mathrm{Ct}$ method (PE, Applied Biosystems) was used to determine relative quantitation of gene expression for each gene compared to the HPRT control (listed in table 2).

\section{Western blotting}

Fifty micrograms of whole proteins extracted from either UN(-) or UN(+) tissues were subjected to SDS-PAGE, and then electrotransferred onto nitrocellulose membranes. Quantitative protein and even transfer in each lane was verified by reversible protein staining of the membranes with $0.1 \%$ Ponceau $S$ in $5 \%$ acetic acid. After blocking in 
$5 \%$ non-fat dry milk, $0.1 \%$ Tween 20 blots were incubated with specific antibodies against Gal-3 (1:100 dilution, Interchim), TCTP (1:5000 dilution, Santa Cruz), IGFBP-7 (1:5000 dilution, Santa Cruz), ODC (1:200 dilution, Sigma) and $\beta$-actin (1:2500 dilution, Sigma) ON at $4^{\circ} \mathrm{C}$. The membranes were then washed and incubated with appropriate horseradish peroxidase conjugated secondary antibody at 1:15 000 (Sigma) for $1 \mathrm{~h}$. All antibodies were diluted in PBS containing 5\% non-fat dry milk. The membranes were reacted with chemiluminescence reagent ECL (Roche Diagnostic) as described by the manufacturer and subsequently exposed to Biomax photographic film (Kodak Corporation). The protein level of the actin housekeeping gene were assayed for internal control of protein loading.

\section{List of abbreviations \\ ARF: Acute Renal Failure}

Calm2: Calmodulin 2

Ftl1: Ferritin light chain 1

Gal-3: Galectin-3

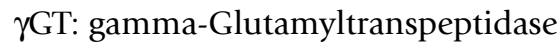

GPx3: Glutathion Peroxidase 3

IGFBP7: Insulin like Growth Factor Binding Protein 7

KAP: Kidney Androgen regulated Protein

KPA: Kinetic Phosphorescence Analyzer

MT-2: Metallothionein 2

NaPi-II: Solute carrier family 34 (sodium phosphate member 1)

ODC: Ornithine Decarboxylase

OPN: Osteopontin

Rps29: Ribosomal protein S29

SAGE: Serial Analysis of Gene Expression

SOD: Superoxide Dismutase

TCTP: Translationally Controlled Tumor Protein

THP: Tamm-Horsfall Protein

U: Uranium

\section{UMOD: Uromodulin}

UN: Uranyl Nitrate

\section{Authors' contributions}

MT carried out the molecular studies, drafted the manuscript, performed the both sequence and statistical analyses and participated in the design of the study. FP and AA participated in the design of the study and participated in the corrections. JD and MCR conceived of the study, participated in its design and in the corrections. All authors read and approved the final manuscript.

\section{Acknowledgements}

The authors would like to thank Christophe Maubert for technical support. We also thank Marie Claraz-Donnadieu and Fabrice Petitot for helpful discussions and Christophe Bonaldi provided stimulating discussion about Monte Carlo analysis.

\section{References}

I. Anthony ML, Gartland KP, Beddell CR, Lindon JC, Nicholson JK: Studies of the biochemical toxicology of uranyl nitrate in the rat. Arch Toxicol 1994, 68(I):43-53.

2. Sun DF, Fujigaki Y, Fujimoto T, Yonemura K, Hishida A: Possible involvement of myofibroblasts in cellular recovery of uranyl acetate-inudced acute renal failure in rats. Am J Pathol 2000, |57(4): |32|-34.

3. Schramm L, La M, Heidbreder E, Hecker M, Beckman JS, Lopau K, Zimmermann J, Rendl J, Reiners C, Winderl S, Wanner C, Schmidt $\mathrm{HH}$ : L-arginine deficiency and supplementation in experimental acute renal failure and in human kidney transplantation. Kidney Int 2002, 6 I (4): 1423-32.

4. Winyard PJ, Bao Q, Hughes RC, Woolf AS: Epithelial galectin-3 during human nephrogenesis and childhood cystic diseases. J Am Soc Nephrol 1997, 8(I I):57.

5. Nishiyama J, Kobayashi S, Ishida A, Nakabayashi I, Tajima O, Miura S, Katayama M, Nogami H: Up-regulation of galectin-3 in acute renal failure of the rat. Am J Pathol 2000, I 57(3):815-23.

6. Verstrepen WA, Persy VP, Verhulst A, Dauwe S, De Broe ME: Renal osteopontin protein and mRNA upregulation during acute nephrotoxicity in the rat. Nephrol Dial Transplant 200I, 16(4):7|2-24

7. Basile DP, Fredrich K, Alausa M, Vio CP, Liang M, Rieder MR, Greene AS, Cowley AW Jr: Identification of persistently altered gene expression in the kidney after functional recovery from ischemic acute renal failure. Am J Physiol Renal Physiol 2005, 288(5):F953-63.

8. Leonard I, Zanen J, Nonclercq D, Toubeau G, Heuson-Stiennon JA, Beckers JF, Falmagne P, Schaudies RP, Laurent G: Modification of immunoreactive EGF and EGF receptor after acute tubular necrosis induced by tobramycin or cisplatin. Ren Fail 1994, 16(5):583-608.

9. Toubeau G, Nonclercq D, Zanen J, Laurent G, Schaudies PR, HeusonStiennon JA: Renal tissue expression of EGF and EGF receptor after ischaemic tubular injury: an immunohistochemical study. Exp Nephrol 1994, 2(4):229-39.

10. Safirstein R: Gene expression in nephrotoxic and ischemic acute renal failure. J Am Soc Nephrol 1994, 4(7): I387-95.

II. Nigam S, Lieberthal W: Acute renal failure. III. The role of growth factors in the process of renal regeneration and repair. Am J Physiol Renal Physiol 2000, 279(I):F3-FII.

12. Kieran NE, Doran PP, Connolly SB, Greenan MC, Higgins DF, Leonard M, Godson C, Taylor CT, Henger A, Kretzler M, Burne MJ, Rabb $H$, Brady HR: Modification of the transcriptomic response to renal ischemic/reperfusion injury by lipoxin analog. Kidney Int 2003, 64:480-92.

13. Mishra J, Ma Q, Prada A, Mitsnefes M, Zahedi K, Yang J, Barasch J, Devarajan P: Identification of neutrophil gelatinase-associated lipocalin as a novel early urinary biomarker for ischemic renal injury. J Am Soc Nephrol 2003, 14( 1 0):2534-43. 
14. Supavekin S, Zhang W, Kucherlapati R, Kaskel FJ, Moore LC, Devarajan P: Differential gene expression following early renal ischemia/reperfusion. Kidney Int 2003, 63(5): 17|4-24.

15. Yoshida T, Tang SS, Hsiao LL, Jensen RV, Ingelfinger JR, Gullans SR Global analysis of gene expression in renal ischemia-reperfusion in the mouse. Biochem Biophys Res Commun 2002, 29 I (4):787-94.

16. Yoshida T, Kurella M, Beato F, Min H, Ingelfinger JR, Stears RL, Swinford RD, Gullans SR, Tang SS: Monitoring changes in gene expression in renal ischemia-reperfusion in the rat. Kidney Int 2002, 6 I(5): 1646-54.

17. Huang $Q$, Dunn RT 2nd, Jayadev S, DiSorbo O, Pack FD, Farr SB, Stoll RE, Blanchard KT: Assessment of cisplatin-induced nephrotoxicity by microarray technology. Toxicol Sci 200I, 63(2): 196-207.

18. Taulan M, Paquet F, Maubert C, Delissen O, Demaille J, Romey MC: Renal toxicogenomic response to chronic uranyl nitrate insult in mice. Environ Health Perspect 2004, I I 2(16): I 628-35.

19. McDonald-Taylor CK, Singh A, Gilman A: Uranyl nitrate-induced proximal tubule alterations in rabbits: a quantitative analysis. Toxicol Pathol 1997, 25:38I-9.

20. Zhang L, Zhou W, Velculescu VE, Kern SE, Hruban RH, Hamilton SR, Vogelstein B, Kinzler KW: Gene expression profiles in normal and cancer cells. Science 1997, 276(53 I6): |268-72.

21. Chabardes-Garonne D, Mejean A, Aude JC, Cheval L, Di Stefano A, Gaillard MC, Imbert-Teboul M, Wittner M, Balian C, Anthouard V, Robert C, Segurens B, Wincker P, Weissenbach J, Doucet A, Elalouf JM: A panoramic view of gene expression in the human kidney. Proc Natl Acad Sci USA 2003, I00(23): 137I 0-5.

22. Cheval L, Virlon B, Billon E, Aude JC, Elalouf JM, Doucet A: Largescale analysis of gene expression: methods and application to the kidney. I Nephrol 2002:SI70-83.

23. Elalouf JM, Aude JC, Billon E, Cheval L, Doucet A, Virlon B: Renal transcriptomes: segmental analysis of differential expression. Exp Nephrol 2002, I0(2):75-8I. 2003

24. Schelling JR, El-Meanawy MA, Barathan S, Dodig T, lyengar SK, Sedor JR: Generation of kidney transcriptomes using serial analysis of gene expression. Exp Nephrol 2002, I 0(2):82-92.

25. Yano N, Endoh M, Fadden K, Yamashita H, Kane A, Sakai H, Rifai A: Comprehensive gene expression profile of the adult human renal cortex: analysis by cDNA array hybridization. Kidney Int 2000, 57(4): I 452-9.

26. El-Meanawy MA, Schelling JR, Pozuelo F, Churpek MM, Ficker EK, lyengar S, Sedor JR: Use of serial analysis of gene expression to generate kidney expression libraries. Am J Physiol Renal Physiol 2000, 279(2):F383-92.

27. Virlon B, Cheval L, Buhler JM, Billon E, Doucet A, Elalouf JM: Serial microanalysis of renal transcriptomes. Proc Natl Acad Sci USA 1999, 96(26): |5286-9|.

28. Heng YM, Kuo CS, Jones PS, Savory R, Schulz RM, Tomlinson SR, Gray TJ, Bell DR: A novel murine P-450 gene, Cyp4a I 4, is part of a cluster of Cyp4a and Cyp4b, but not of CYP4F, genes in mouse and humans. Biochem J 1997, 325(Pt 3):741-9.

29. Kwon TH, Froklaer J, Huan JS, Knepper MA: Decreased abundance of major $\mathrm{Na}+$ transporters in kidneys of rats with ischemia-induced acute renal failure. Am J Physiol Renal Physio 2000, 278:F925-39.

30. Kas K, Stickens D, Merregaert J: Characterization of a processed pseudogene of human FAUI on chromosome 18. Gene 1995 I 60(2):273-6

31. Fujigaki $Y$, Sun DF, Goto $T$, Hishida A: Temporary changes in macrophages and MHC class-II molecule-expressing cells in the tubulointerstitium in response to uranyl acetate-induced acute renal failure in rats. Virchows Arch 2003, 443(2):206-16

32. Mavromatidis K, Fytil C, Kynigopoulou P, Fragia T, Sombolos K: Serum ferritin levels are increased in patients with acute renal failure. Clin Nephrol 1998, 49(5):296-8.

33. Velculescu VE, Zhang L, Vogelstein B, Kinzler KW: Serial analysis of gene expression. Science 1995, 270(5235):484-7.

34. Sun DF, Fujigaki $Y$, Fujimoto $T$, Goto $T$, Yonemura K, Hishida A Relation of distal nephron changes to proximal tubular damage in uranyl acetate-induced acute renal failure in rats. Am J Nephrol 2002, 22(5-6):405-16.

35. Rabinovich GA, Baum LG, Tinari N, Paganelli R, Natoli C, Liu FT, lacobelli S: Galectins and their ligands: amplifiers, silencers or tuners of the inflammatory response? Trends Immunol 2002, 23(6):3| $3-20$
36. Liu FT, Patterson RJ, Wang JL: Intracellular functions of galectins. Biochem Biophys Acta 2002, 1572:263-273.

37. Cheng RY, Zhao A, Alvord WG, Powell DA, Bare RM, Masuda A, Takahashi T, Anderson LM, Kasprzak KS: Gene expression doseresponse changes in microarrays after exposure of human peripheral lung epithelial cells to nickel(II). Toxicol Appl Pharmacol 2003, I 91 (I):22-39.

38. Davis SR, Cousins RJ: Metallothionein expression in animals: a physiological perspective on function. I Nutr 2000, 130: 1085-1088.

39. Bleyer AJ, Trachtman H, Sandhu J, Gorry MC, Hart TC: Renal manifestations of a mutation in the uromodulin (Tamm Horsfall protein) gene. Am J Kidney Dis 2003, 42(2):E20-6.

40. Katsuma S, Shiojima S, Hirasawa A, Takagaki K, Kaminishi Y, Koba M, Hagidai Y, Murai M, Ohgi T, Yano J, Tsujimoto G: Global analysis of differentially expressed genes during progression of calcium oxalate nephrolithiasis. Biochem Biophys Res Commun 2002, 296(3):544-52.

4I. Fleck C, Sutter L, Appenroth D, Koch B, Meinhold T, Pitack M, Gasser $R$ : Use of gene chip technology for the characterisation of the regulation of renal transport processes and of nephrotoxicity in rats. Exp Toxicol Pathol 2003, 54(5-6):40I-I0.

42. Kramer DL, Chang BD, Chen Y, Diegelman P, Alm K, Black AR, Roninson IB, Porter CW: Polyamine depletion in human melanoma cells leads to GI arrest associated with induction of p2 IWAFI/CIPI/SDII, changes in the expression of $\mathrm{p} 2 \mathrm{I}$-regulated genes, and a senescence-like phenotype. Cancer Res 200I, 6 I (2I):7754-62.

43. Cebrian C, Areste C, Nicolas A, Olive P, Carceller A, Piulats J, Meseguer $A$ : Kidney androgen-regulated protein interacts with cyclophilin B and reduces cyclosporine A-mediated toxicity in proximal tubule cells. J Biol Chem 200I, 276(3I):294I0-9.

44. Khanna N, Sen S, Sharma H, Singh N: S29 ribosomal protein induces apoptosis in $\mathbf{H 5 2 0}$ cells and sensitizes them to chemotherapy. Biochem Biophys Res Commun 2003, 304(I):26-35.

45. Wilson EM, Oh Y, Hwa V, Rosenfeld RG: Interaction of IGF-binding protein-related protein I with a novel protein, neuroendocrine differentiation factor, results in neuroendocrine differentiation of prostate cancer cells. J Clin Endocrinol Metab 200I, 86(9):4504-II.

46. Degeorges A, Wang F, Frierson HF Jr, Seth A, Sikes RA: Distribution of IGFBP-rPI in normal human tissues. J Histochem Cytochem 2000, 48(6):747-54.

47. Sturzenbaum SR, Kille P, Morgan AJ: Identification of heavy metal induced changes in the expression patterns of the translationally controlled tumour protein (TCTP) in the earthworm Lumbricus rubellus. Biochim Biophys Acta 1998, I 398(3):294-304.

48. Bommer UA, Thiele BJ: The translationally controlled tumour protein (TCTP). Int | Biochem Cell Biol 2004, 36(3):379-85

49. Cans C, Passer B], Shalak V, Nancy-Portebois V, Crible V, Amzallas $\mathrm{N}$, Allanic D, Tufino R, Argentini M, Moras D, Fiucci G, Goud B, Mirande M, Amson R, Telerman A: Translationally controlled tumor protein acts as a guanine nucleotide dissociation inhibitor on the translation elongation factor eEFIA. Proc Natl Acad Sci USA 2003, 100(24): I 3892-7.

50. Ejnik JW, Hamilton MM, Adams PR, Carmichael AJ: Optimal sample preparation conditions for the determination of uranium in biological samples by kinetic phosphorescence analysis (KPA). J Pharm Biomed Anal 2000, 24(2):227-35

51. For construction SAGE (Serial Analysis of Gene Expression) libraries [http://www.invitrogen.com/content/sfs/manuals/ sage man.pdf

52. National Center for Biotechnology Information. Gene Expression Omnibus [http://www.ncbi.nlm.nih.gov/geo/] 